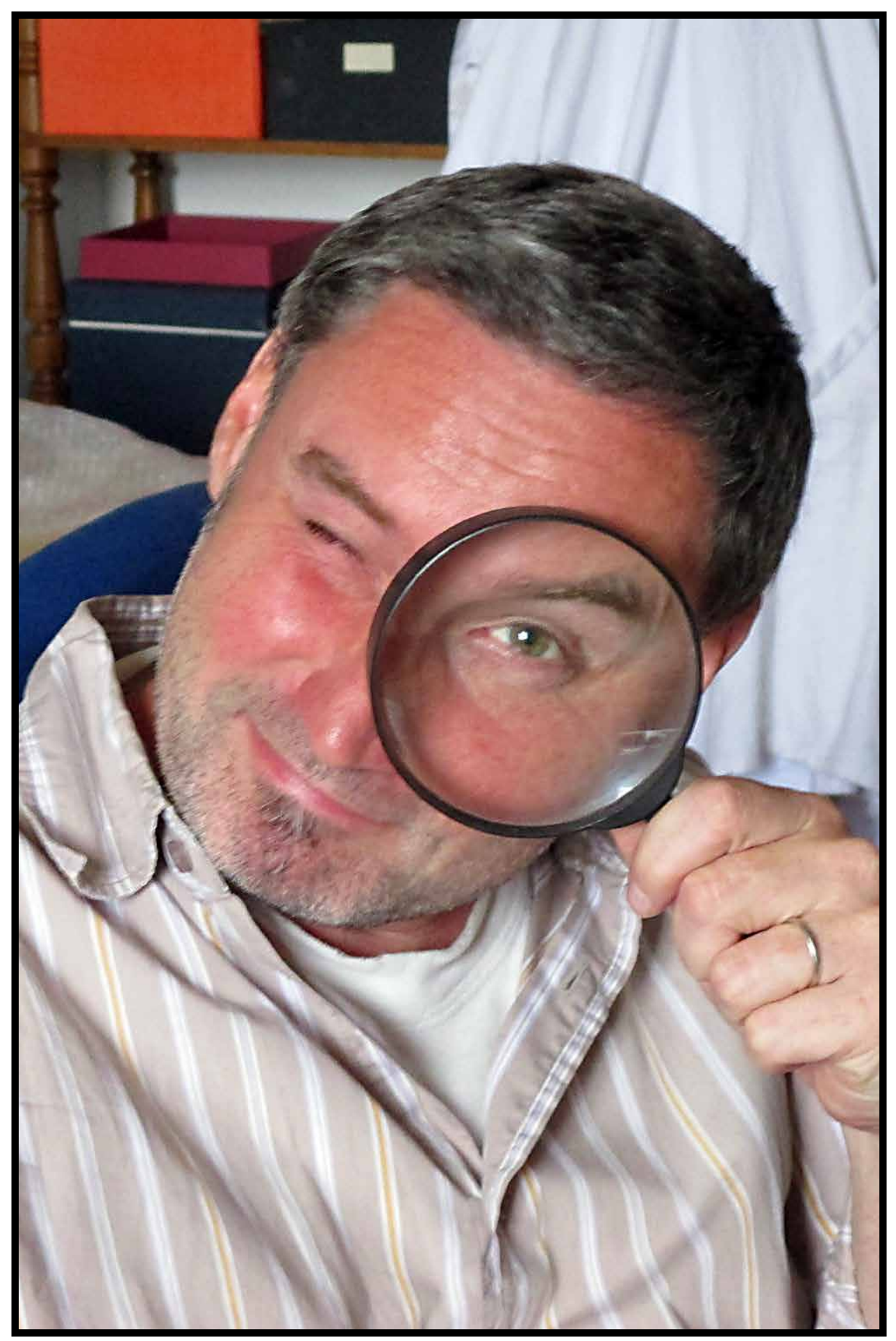

Vlastimil Novák ${ }^{1}$ 


\section{Vlastimil Novák \\ (September 9, 1964 - June 6, 2020)}

After losing his long-term battle with a serious illness, the untimely death of prominent numismatist and orientalist PhDr. Vlastimil Novak, Ph.D. on June 6, 2020 at the age of 55 has hit all of us very hard.

After studying at the Faculty of Arts at Charles University, Novák joined the Náprstek Museum in 1990, where he succeeded Jarmila Štěpková and became her pupil and later her friend. The Náprstek Museum became his lifelong workplace where he managed the local numismatic collection and worked as a researcher. Shortly after his arrival, Novák developed into a leading and in fact the only Czech specialist in oriental and especially Islamic numismatics; this was made possible among other things by his profound knowledge of European languages and also Arabic.

The spectrum of Novák's numismatic interests was remarkably broad, which is also reflected in his extensive bibliography. Above all, it is necessary to recall his monographic works and important studies. In 2000 (along with J. Militký) he published the electronic publication Numismata Orientalia Regni Bohemiae - Corpus Sasanicus - a complete database and annotated catalogue of all Sasanian coins available at that time from public and private collections in the Czech Republic. At the time, it was a truly unique publication project supported by the Czech Science Foundation.

In 2002, an extensive work was published (along with J. Militký) on the topic of coin finds originating from the archaeological excavations of Bedřich Hrozný in the Middle East - Greek, Roman, Byzantine, and Islamic Coins Excavated by Bedrich Hrozný in the Middle East (1924-1925), published in the Annals of the Náprstek Museum.

Another important work is from 2006 and was focused on the issue of glass weights and tokens from the collection of Josef Michera - The Josef Michera Collections: Roman, Early-Byzantine, Islamic and Late Medieval Glass Weights, Vessel Stamps and Jetons. This work was also very pioneering in many respects, as it provided a consistent mapping of insufficiently published material. This publication builds on a previous study Fatimid and Post-Fatimid Glass Jetons in the National Museum, Prague, published in 1997 in The Numismatic Chronicle.

In 2011, (along with J. Kolbas and T. May) a monograph was published which made available the data on an interesting find of Islamic medieval silver coins - Anatolian Early $14^{\text {th }}$ Century Coin Hoard. In the same year, the major monograph A Survey of the Coinage of the Seljuqs of Rum was published in London. This book, authored by M. Broome, was edited by Novák after the author's death, and this work still remains to this day the primary reference catalogue on the issue. Novák's major publications also include an online database of 3,600 Islamic coins from the Fitzwilliam Museum in Cambridge (available at: https://www.fitzmuseum.cam.ac.uk/aboutus/coins). It is one of the largest published collection databases. Novák diligently worked on this project for many years.

1 Photo: Dagmar Pospíšilová.

This work is licensed under the Creative Commons Attribution-Noncommercial-No Devivs 3.0 License 
In 2013, (along with Irakli Paghava) a study was published making available a collection of Georgian coins from the Náprstek Museum - Georgian Coins in the Collection of the National Museum-Náprstek Museum in Prague, published in the Annals of the Náprstek Museum.

Novák also systematically dealt with Islamic finds originating from the territory of the Czech Republic. In 2010, he compiled a monograph detailing the Islamic component of the early medieval hoard of hacksilver from Kelč - The Kelč Hoard Revised: Fragments of Islamic Silver Coins. In 2016, (along with J. Videman, P. Kouřil, L. Richter, and M. Zmrzlý) he published another book concerning the early medieval treasure of broken silver from the territory of Moravia - Depot mincí a zlomkového střibra z konce 10. století nalezený $v$ Kojetině-Popũvkách/ A Hacksilver Hoard Dating from the End of the $10^{\text {th }}$ Century and Found in Kojetin-Popuoky. Both books represent the basic pillars of knowledge concerning the problem of the occurrence of hacksilver from the $11^{\text {th }}$ century, which as a phenomenon spreads to the Czech Republic from Poland.

For Central Europe, Vlastimil Novák became a crucial researcher concerning the problem of finds of coins of the Ottoman Empire, and he published a number of publications on this topic. Among them, we can mention, for example, the article (along with M. Budaj and J. Hunka) Nové nálezy tureckých mincí zo Slovenska (New Finds of Turkish Coins from Slovakia) from 2005, published in the Numismaticky sbornik. In recent years, he revised all of the Ottoman finds from the Czech Republic, but unfortunately did not live to see their publication. This was a paper published in the Numismatický sborník entitled Nové nálezy osmanských mincí na území České republiky z let 1996-2018 (New Finds of Ottoman Coins in the Czech Republic from 1996-2018). He also dealt with this topic in a yet unpublished collective monograph (along with J. Militký, F. Hradil, A. Knápek, K. Smíšek, and E. Vilimec) entitled Poklad mincí z doby trricetileté války z Horních Rápotic (Treasure of Coins from the Thirty Years' War in Horní Rápotice). The largest number of small contributions by Novák about coin finds in the Czech Republic is focused on Ottoman minting.

In addition to the above works, Novák is the author of dozens of other articles, reports on findings, and conference papers. However, Novák's role in domestic numismatic science includes another and at first glance somewhat hidden dimension of his work - translations of summaries in the Numismatický sbornik, Numismatické listy, and in a number of books. There are indeed hundreds of texts that have made the results of domestic research available to the entire professional world, and this work truly deserves an extraordinary appreciation.

As the collected bibliography and overview of other activities show, Vlastimil Novák actively participated in a number of exhibitions at home and abroad and contributed to exhibition catalogues. Together with colleagues from the numismatic department of the National Museum, he also participated in the preparation of the permanent exhibition, although he did not live to see its anticipated realization.

The passing of Vlastimil Novák is a great loss for Czech and world numismatics. Unfortunately, his passing represents an irreplaceable and incomparable loss which the field of numismatics will struggle to deal with for a long time to come. However, Vlastimil Novák's scientific and academic legacy will certainly be significant for many decades, and moreover, many of his texts are still awaiting publication. However, nothing can replace a rare and unique person, friend, and companion who for the current numismatic generation will be forever missed. 